\title{
Effect of virus-rich high molecular weight concentrates of seawater on the dynamics of dissolved amino acids and carbohydrates
}

\author{
Markus G. Weinbauer*, Peter Peduzzi \\ Institute of Zoology, University of Vienna, Althanstrasse 14, A-1090 Vienna, Austria
}

\begin{abstract}
The effect of moderately (about 2.5-fold) increasing the virus-rich high molecular weight fraction concentrates (HMWC) in seawater on dissolved organic matter (DOM) was tested in an experimental approach. At the start of the experiments, the HMWC enrichment did not significantly change bacterial abundances and concentrations of chl a and DOM compounds, whereas viral abundances increased about 2.0 - to 2.3 -fold. During short-term experiments $(<40 \mathrm{~h})$, dissolved amino acids and carbohydrates were stimulated by the addition of HMWC; an increase in bacterial numbers then followed. During long-term experiments (from about 60 up to $210 \mathrm{~h}$ ), bacterial abundances were repressed, and the percentage of visibly infected bacteria was significantly higher in the virus-rich HMWC incubations. Rod-shaped bacteria were the only morphotype affected by the HMWC. HMWC delayed the development of phytoplankton (diatoms); but, at the end of the experiments, chl a concentrations in the HMWC-treated incubations exceeded that in the untreated incubations. The stimulation of Ser and Thr in the dissolved hydrolysable amino acid fraction of the HMWC incubations might be an indication of viral lysis of diatom cells. Dissolved free amino acids and monomeric carbohydrates were repressed, whereas dissolved hydrolysable as well as total dissolved amino acids and carbohydrates were stimulated by the addition of HMWC. Viral lysis of cells, flagellate grazing and changes in bacterial number or species compositon are the most probable reasons for the observed changes in the DOM pool.
\end{abstract}

KEY WORDS: Viruses - Bacteria - Phytoplankton - Dissolved organic matter - Dissolved amino acids Dissolved carbohydrates

\section{INTRODUCTION}

Virus-like particles can be as large as $0.75 \mu \mathrm{m}$ (Gowing 1993), but most marine viruses are smaller than $0.2 \mu \mathrm{m}$ (Bergh et al. 1989, Wommack et al. 1992, Cochlan et al. 1993, Weinbauer et al. 1993) and, thus, have to be considered as part of the pool of dissolved organic matter (DOM). Viruses are now known as the most abundant forms of life in the oceans (e.g. Bergh et al. 1989, Proctor \& Fuhrman 1990). Based on the finding that all numerically important taxonomic groups of planktonic organisms can be infected with viruses (Sieburth et al. 1988, Bratbak et al. 1990, Proctor \&

\footnotetext{
- Present address: Marine Science Institute, The University of Texas at Austin, Port Aransas, Texas 78373-1267, USA

E-mail: markusw@utmsi.zo.utexas.edu
}

Fuhrman 1990, Suttle et al. 1990, Nagasaki et al. 1993), the question of viral-mediated mortality and its significance was raised. Moreover, viruses were included in a model of carbon transfer within the microbial loop (Bratbak et al. 1992) and bacteriophage production was found to depend on the density of host organisms (Steward et al. 1992, Weinbauer \& Peduzzi 1994). There is also some information accumulating at present on the spatiotemporal distribution of viruses in the sea (Wommack et al. 1992, Boehme et al. 1993, Cochlan et al. 1993, Paul et al. 1993, Weinbauer et al. 1993, Jiang \& Paul 1994, Weinbauer et al. 1995).

High molecular weight concentrates (HWMC) of seawater (between $30000 \mathrm{MW}$ and $0.2 \mu \mathrm{m}$, and between $100000 \mathrm{MW}$ and $0.2 \mu \mathrm{m}$ ) have been used to study the effect of viruses on the mortality and dynamics of phytoplankton, bacteria and heterotrophic nanoflagel- 
lates (Proctor \& Fuhrman 1990, 1992, Suttle et al. 1990, Suttle 1992, Peduzzi \& Weimbauer 1993b). HMWC were also found to stimulate the formation of algal flocs (Peduzzi \& Weinbauer 1993a). However, although viruses were found to be the most abundant particles in the concentrates, there might exist other bioactive material in the HMWC, as, e.g., colloids and proteins.

By comparing different approaches it has been estimated that about 10 to $20 \%$ of the marine bacterial community is lysed daily by phages, and about 2 to $3 \%$ of primary production is lost through the activity of viruses (Suttle 1994). Viral lysis of cells releases not only viruses, but also cell wall components and other cell constituents. Thus, the 'viral loop' (Bratbak et al. 1992) should increase DOM concentrations and bacterial production, but reduce the carbon transfer to higher trophic levels (Fuhrman 1992). Models indicate that the importance of this process varies with the eutrophication of the system (Murray \& Eldridge 1994). However, there is still only little information on the role viruses play in microbial carbon transfer (Bratbak et al. 1994). In the present laboratory study, we show that moderately increasing the virus-rich high molecular weight fraction of seawater increased the percentage of visibly infected bacteria and resulted in changes in the concentrations and chemical composition of selected DOM components.

\section{MATERIALS AND METHODS}

Seawater was collected with carboys from $0.5 \mathrm{~m}$ depth off the Laboratorio di Biologia Marina at Aurisina, Italy, and transported to the laboratory for immediate use in the experiments.

Production of high molecular weight concentrates. To produce virus-rich HMWC, ultrafiltration technology was used as described in detail by Suttle et al. (1991). First between 60 and $90 \mathrm{l}$ of seawater were gently prefiltered through $142 \mathrm{~mm}$ diameter polycarbonate (Millipore, 'Isopore' RTTP, $1.2 \mu \mathrm{m}$ pore size, and subsequently 'Isopore' GTTP, $0.2 \mu \mathrm{m}$ pore size) membrane filters to remove zooplankton, phytoplankton and most of the bacterioplankton cells. Then, using an AMICON ultrafiltration system, this prefiltered seawater was concentrated by a spiral cartridge with a $30000 \mathrm{MW}$ cutoff, which is equivalent to about $2 \mathrm{~nm}$. The retentate of this filtration process is a virus-rich HMWC with a concentration factor between 80 and 90 . For details of the procedure see Peduzzi \& Weinbauer (1993b)

Experimental setup. HMWC were added to $10 \mathrm{I}$ acid-rinsed polyethylene jars (Expt 1) or $5 \mathrm{l}$ acidrinsed precombusted $\left(450^{\circ} \mathrm{C}\right.$ for $\left.4.5 \mathrm{~h}\right)$ glass jars (silicon cap) (Expts 2 and 3), achieving a final enrich- ment factor of 2.5x. In Expt 1, seawater was amended with HMWC obtained in January 1992. Temperature was kept at 17 to $18^{\circ} \mathrm{C}$ and the light intensity at $300 \mu \mathrm{E} \mathrm{m} \mathrm{m}^{2} \mathrm{~s}^{-1}$ (12 h light: $12 \mathrm{~h}$ dark), representative of spring-bloom events. HMWC obtained in June 1992 were added to seawater collected at 2 different stations off the Laboratorio di Biologia Marina (Expts 2 and 3). Temperature was kept at 22 to $23^{\circ} \mathrm{C}$ and light intensity at $350 \mu \mathrm{E} \mathrm{m}^{-2} \mathrm{~s}^{-1}$ (Expt 2) and $250 \mu \mathrm{E} \mathrm{m}^{-2} \mathrm{~s}^{-1}$ (Expt 3), thus simulating in situ conditions. Experiments were performed in triplicate incubations.

Determination of microbial parameters. Water samples for the enumeration of viral and bacterial densities were withdrawn through a silicone-stopper-sealed sample port by means of pipettes, preserved with formalin (viruses $2 \%$ and bacteria $4 \%$, final conc.) and stored at $4^{\circ} \mathrm{C}$ in the dark until analysis. Virus particle abundance was determined using the ultracentrifugation methodology for harvesting viruses directly onto Formvar coated, 400-mesh electron microscope grids (2.5 h at $85000 \times 9 ;$ Beckman L8-80M, SW 41 Ti swingout rotor) as described by Mathews \& Buthala (1970), Børsheim et al. (1990) and Bratbak et al. (1990). The percentage of bacteria containing mature phages was determined by the use of electron microscopy as described in Weinbauer \& Peduzzi (1994). Bacterial densities were determined with the AODC technique (Hobbie et al. 1977). Grids (viruses, infected bacteria) and slides (bacteria) were prepared within $1 \mathrm{wk}$. Chl a was measured by withdrawing aliquots of the incubation media from the jars and filtering onto GF/F (Whatman) filters. Chl a-containing filters were stored frozen until analysed as described in Parsons et al. (1984).

Determination of DOM. Water samples for the determination of various compounds of DOM were gravity filtered through precombusted $\left(450^{\circ} \mathrm{C}\right.$ for $\left.4.5 \mathrm{~h}\right) \mathrm{GF} / \mathrm{F}$ filters and stored frozen in precombusted glass ampoules. In Expts 1 and 2, the concentrations of dissolved free amino acids (DFAA) and total dissolved amino acids (TDAA) were determined by high pressure liquid chromatography using the o-phthalaldehyde (OPA) reversed phase method (Mopper \& Lindroth 1982). In Expt 3, dissolved free OPA-reactive compounds (DFORC) and total dissolved OPA-reactive compounds (TDORC) were measured by the OPA method as described by Parsons et al. (1984). By the latter method not only amino acids, but also primary amines, are determined. Dissolved monomeric carbohydrates (DM$\mathrm{CHO}$ ) and total dissolved carbohydrates (TDCHO) were measured by the 3-methyl-2-benzothiazolinone hydrazone hydrochloride (MBTH) assay (Parsons et al. 1984). Samples for TDAA, TDORC and TDCHO were hydrolysed under nitrogen for $22 \mathrm{~h}$ at $110^{\circ} \mathrm{C}$ using $6 \mathrm{~N}$ $\mathrm{HCl}$ (final conc.) (compare Heissenberger \& Herndl 1994). After hydrolysis $\mathrm{HCl}$ was removed by evaporat- 
ing the samples at $5^{\circ} \mathrm{C}$ under vacuum (200 mtorr). Dried samples were rehydrated with HPLC-grade water for the OPA-reversed phase method and with Milli-Q water for the total OPA-reactive compound and $\mathrm{MBTH}$ assays. Samples were neutralized with small amounts of $0.05 \mathrm{~N} \mathrm{NaOH}$, and salt crystals were dissoluted completely by ultrasonication for $2 \mathrm{~min}$. In the present study, dissolved combined amino acids (DCAA) are defined by subtraction of DFAA from TDAA and dissolved combined OPR-reactive compounds (DCORC) by subtracting DFORC from TDORC, whereas dissolved polymeric carbohydrates (DPCHO) are calculated as the difference between DMCHO and TDCHO. DFAA and DTAA concentrations were calculated as the sum of all detectable amino acids.

Statistical analysis. The Mann-Whitney $U$-test was used to test differences of microbial and DOM parameters between HMWC-enriched and unaltered incubations for significance. Differences were compared at single time points of the experiments and considered as significant at a probability of $p \leq 0.05$.

\section{RESULTS}

\section{Initial concentration of parameters}

Immediately after incubating jars with HMWC, all parameters were determined in the unaltered as well as HMWC-enriched incubations. In no experiments did the HMWC enrichment result in significant changes in abundances of bacteria or concentrations of chl $a$ and of the various investigated DOM compounds (Table 1). Averaging the stimulation/repression values of the various parameters from all experiments sampled immediately after adding HMWC yielded stimulation/repression values which were always below $10 \%$ for each of the parameters. Viruses were the only investigated parameter exhibiting a significant enrich- ment after addition of HMWC: an approximately 2.5fold enrichment with HMWC (final conc.) resulted in an increase in viral abundance by a factor of 2.0 to 2.3 . Table 1 also shows that the initial concentrations of some parameters varied strongly among the 3 experiments, but not between the 2 different treatments

\section{Short-term experiment}

Fig. 1 shows the development of bacterial densities, dissolved amino acid and carbohydrate concentrations in unaltered and enriched incubations of unfiltered seawater during the first $40 \mathrm{~h}$ (Expt 1). In both treatments bacteria showed a strong peak at 18 and $28 \mathrm{~h}$. At both time points the bacterial abundance was significantly higher in the enriched incubations than in untreated seawater. DFAA and DCAA concentrations decreased dramatically after $5.5 \mathrm{~h}$ concomitant with the increase of bacterial densities. At $5.5 \mathrm{~h}$ in the enriched cultures, DFAA and DCAA concentrations showed a slight peak and amino acid concentrations were significantly higher than in the untreated incubations. Overall DMCHO and DPCHO concentrations peaked at $5.5 \mathrm{~h}$ followed by a decrease in the concentrations with increasing bacterial abundances. $\mathrm{DMCHO}$ and $\mathrm{DPCHO}$ concentrations were significantly higher in the enriched than in the untreated cultures. Between 5.5 and $40 \mathrm{~h}$ bacterial abundance in HMWC enriched seawater was up to $33 \%$ higher than in unaltered incubations, DFAA were stimulated by up to $200 \%$, DMCHO concentrations by up to $29 \%$, DCAA up to $50 \%$, and DPCHO up to $77 \%$.

\section{Long-term experiments}

Diatoms, especially Chaetoceros sp., dominated the phytoplankton community in all experiments and in-

Table 1. Abundances \pm SD of microbial parameters and concentrations of the various DOM compounds in HMWC-enriched (Vir) and unaltered (Cont) incubations in 3 experiments immediately after addition of the HMWC. VA: viral abundance, BA: bacterial abundance, Chl a: chlorophyll $a$, DFAA: dissolved free amino acids, DCAA: dissolved combined amino acids, DMCHO: dissolved monomeric carbohydrates, DPCHO: dissolved polymeric carbohydrates. SD calculated from triplicate incubations

\begin{tabular}{|c|c|c|c|c|c|c|c|c|}
\hline Expt & Treatment & $\begin{array}{c}V A \\
\left(10^{6} \mathrm{ml}^{-1}\right)\end{array}$ & $\begin{array}{c}\mathrm{BA} \\
\left(10^{5} \mathrm{ml}^{-1}\right)\end{array}$ & $\begin{array}{c}\text { Chl a } \\
\left(\mu \mathrm{gl} \mathrm{l}^{-1}\right)\end{array}$ & $\begin{array}{l}\text { DFAA } \\
(\mu \mathrm{M})\end{array}$ & $\begin{array}{c}\text { DCA.A } \\
(\mu \mathrm{M})\end{array}$ & $\begin{array}{c}\text { DMCHO } \\
(\mu \mathrm{M})\end{array}$ & $\begin{array}{c}\text { DPCHO } \\
(\mu \mathrm{M})\end{array}$ \\
\hline \multirow[t]{2}{*}{1} & Cont & $11.6 \pm 1.02$ & $2.9 \pm 0.23$ & $0.62 \pm 0.032$ & $1.1 \pm 0.011$ & $4.0 \pm 0.27$ & $4.0 \pm 0.16$ & $14.0 \pm 0.97$ \\
\hline & Vir & $26.7 \pm 1.93$ & $3.4 \pm 0.33$ & $0.62 \pm 0.071$ & $1.2 \pm 0.005$ & $3.6 \pm 0.49$ & $4.4 \pm 0.45$ & $16.3 \pm 1.75$ \\
\hline \multirow[t]{2}{*}{2} & Cont & $4.9 \pm 0.58$ & $1.5 \pm 0.12$ & $0.49 \pm 0.055$ & $0.082 \pm 0.0039$ & $2.2 \pm 0.11$ & $3.1 \pm 0.24$ & $16.9 \pm 1.44$ \\
\hline & Vir & $10.9 \pm 0.99$ & $1.3 \pm 0.23$ & $0.50 \pm 0.043$ & $0.098 \pm 0.0041$ & $2.4 \pm 0.12$ & $3.3 \pm 0.17$ & $17.7 \pm 1.09$ \\
\hline \multirow[t]{2}{*}{3} & Cont & $2.5 \pm 0.24$ & $2.2 \pm 0.24$ & $0.45 \pm 0.067$ & $0.30 \pm 0.054$ & $2.6 \pm 0.32$ & $4.2 \pm 0.27$ & $10.6 \pm 1.07$ \\
\hline & Vir & $5.1 \pm 0.47$ & $2.1 \pm 0.19$ & $0.43 \pm 0.035$ & $0.35 \pm 0.019$ & $2.6 \pm 0.25$ & $4.0 \pm 0.27$ & $11.6 \pm 2.3$ \\
\hline
\end{tabular}



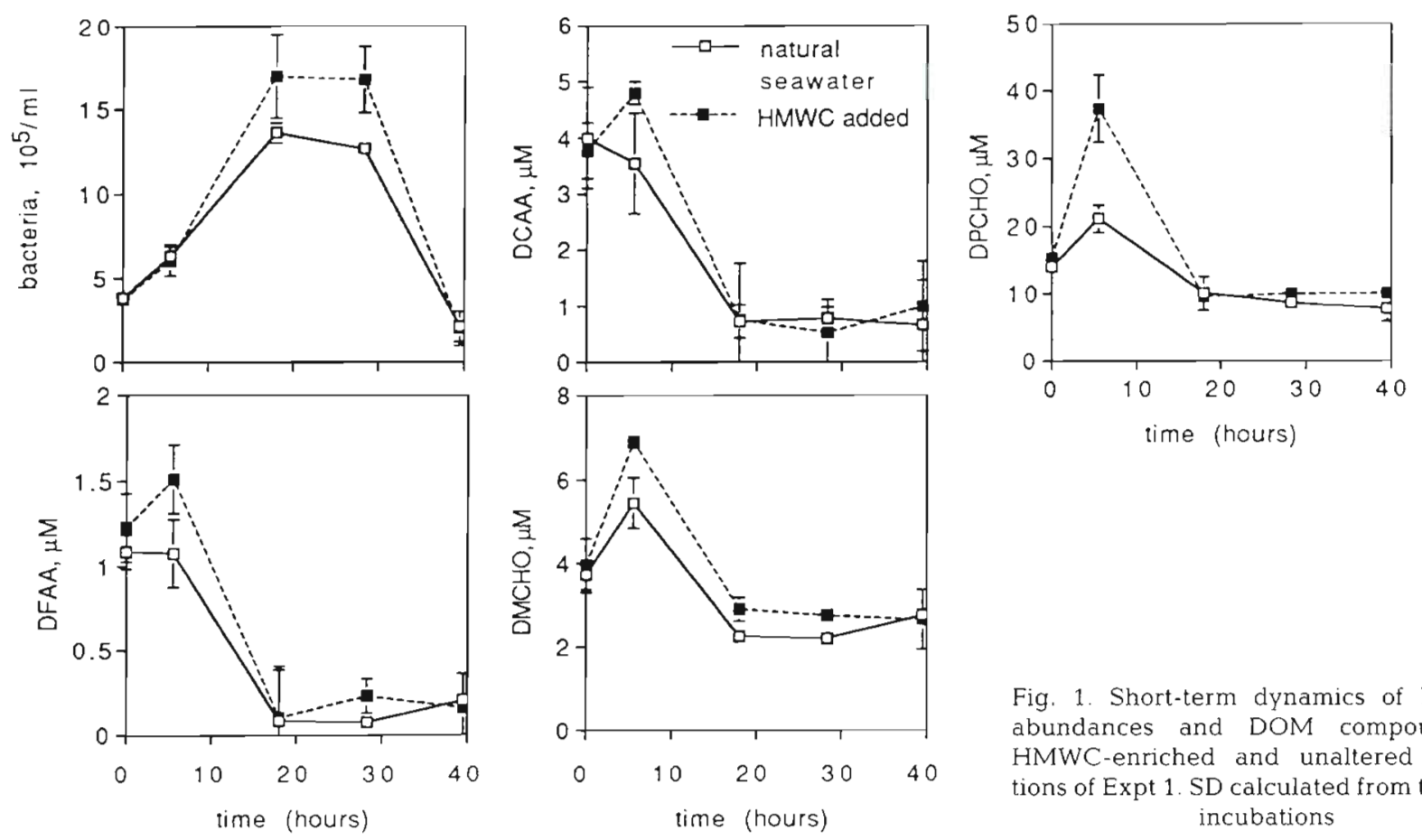

Fig. 1. Short-term dynamics of bacterial abundances and DOM compounds in HMWC-enriched and unaltered incubations of Expt 1. SD calculated from triplicate incubations

cubations. During Expt 1 we followed the temporal development of chl $a$ in HMWC-treated and unaltered incubations. During the first $168 \mathrm{~h}$ of the experiment, chl a concentrations were significantly repressed in the incubations amended with HMWC compared to unaltered incubations but higher at the end of the experiment after 208 h (Fig. 2). Similarly, at the end of Expts 2 and 3 , chl a concentrations were significantly higher in the incubations receiving HMWC (Fig. 2).

At all time points of Expt 1 (long-term), the percentage of visibly infected bacteria was higher in HMWC

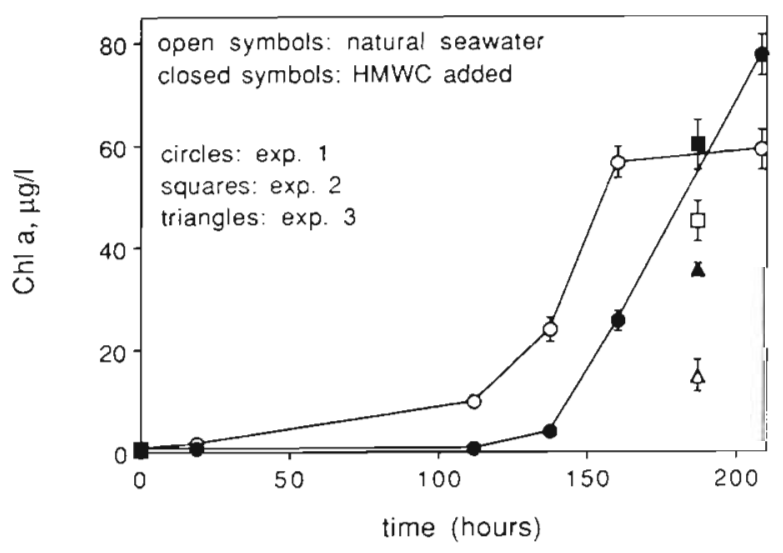

Fig. 2. Chl a concentrations in HMWC-ennched and unaltered incubations. SD calculated from triplicate incubations than in natural seawater incubations, and in 4 out of 6 time points this difference was significant (Fig. 3). The average percentage of bacteria containing mature phages, calculated from Fig. 3, was 1.7 in the natural seawater and 2.5 in the HMWC incubation (Table 2). In rod-shaped bacteria, the most abundant morphotype (Table 2), the percentage of visibly infected cells was, at 5 time points, significantly higher in HMWC than in untreated incubations. At no time point did the percentage of visibly infected cells of the other morphotypes or the relative abundances of the different morphotypes differ significantly between the 2 treatments.

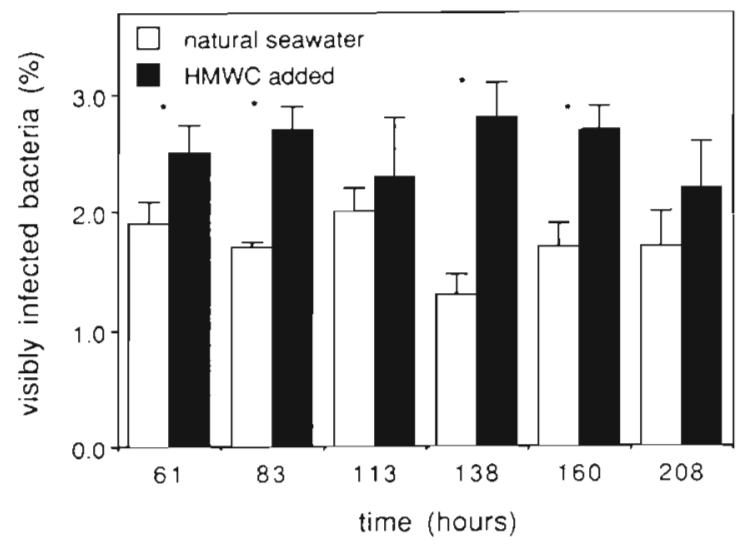

Fig. 3. Percentage of visibly infected bacteria in HMWCenriched and unaltered incubations of Expt 1 -Significant difference between treatments ( $p \leq 0.05)$. SD calculated from triplicate incubations 
Table 2. Viral and bacterial abundances \pm SD and percentage of bacterial morphotypes containing mature phages in natural seawater (Cont) and HMWC-enriched (Vir) incubations during the long-term Expt 1. Values are averaged from all data obtained during the incubation time ( $>40$ to $208 \mathrm{~h}$ ). VA: viral abundance, BA: bacterial abundance

\begin{tabular}{|lccccccccc}
\hline Treatment & $\begin{array}{c}\text { VA } \\
\left(10^{7} \mathrm{ml}^{-1}\right)\end{array}$ & $\begin{array}{c}\text { BA } \\
\left(10^{5} \mathrm{ml}^{-1}\right)\end{array}$ & Rods & $\begin{array}{c}\text { \% of total } \\
\text { Cocci }\end{array}$ & Spirillae & Rods & $\begin{array}{c}\text { Visibly infected cells (\%) } \\
\text { Cocci }\end{array}$ & Spirillae & Total \\
\hline Cont & $1.1 \pm 1.27$ & $9.0 \pm 5.14$ & $82.3 \pm 8.21$ & $13.5 \pm 4.91$ & $4.2 \pm 1.62$ & $1.5 \pm 0.19$ & $3.3 \pm 0.90$ & $1.4 \pm 0.36$ & $1.7 \pm 0.24$ \\
$\operatorname{Vir}$ & $2.4 \pm 1.14$ & $6.7 \pm 3.78$ & $79.1 \pm 9.92$ & $15.6 \pm 3.32$ & $5.3 \pm 2.99$ & $2.4 \pm 0.21$ & $3.5 \pm 0.45$ & $1.6 \pm 0.42$ & $2.5 \pm 0.24$ \\
\hline
\end{tabular}

Of all morphotypes, coccoid bacteria showed the highest percentage of cells containing mature phages (Table 2). Viral abundances at all time points were significantly higher in the HMWC than in untreated incubations, whereas bacterial numbers were significantly lower at 4 time points. The addition of HMWC resulted in a long-term enrichment of viral abundances by a factor of 2.2 (Table 2).

Long-term data (>60 h) on bacterial abundances and concentrations of DOM parameters were obtained from all experiments. In all experiments bacteria were generally repressed in the long term by the addition of HMWC, although at some sampling times there was a stimulation of the bacteria compared to unaltered incubations, e.g. at about $150 \mathrm{~h}$ in Expt 2 (Fig. 4). Calculating long-term stimulation/repression of bacteria from the means of the 3 experiments yielded bacterial repression values for the HMWC treatments which averaged $29 \%$.

In Expts 1 and 2 dissolved amino acids were determined, whereas in experiment 3 we measured OPAreactive compounds. DFAA were generally repressed (Fig. 5), and this repression, calculated from the mean values of the 2 experiments, averaged $23 \%$. DCAA and TDAA were generally stimulated when natural

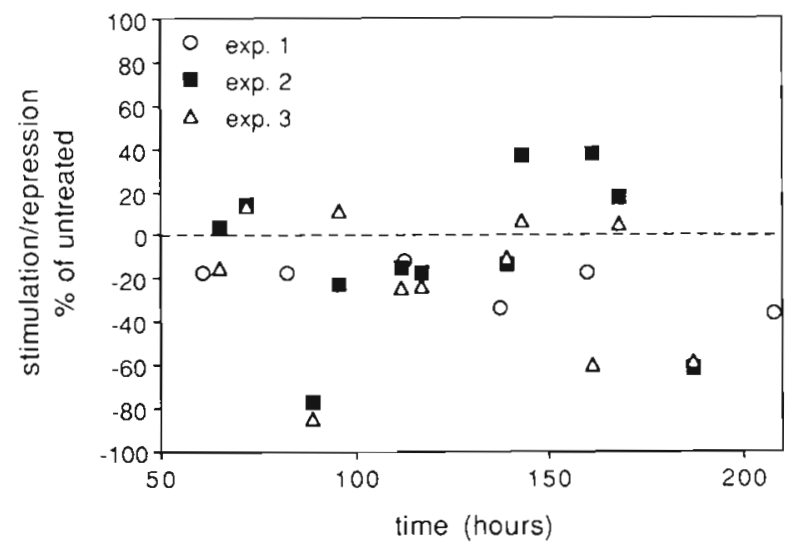

Fig. 4. Long-term stimulation/repression data of bacteria during all 3 experiments. Each data point represents the $\%$ change of bacterial abundance in HMWC enriched incubations compared to unaltered incubations

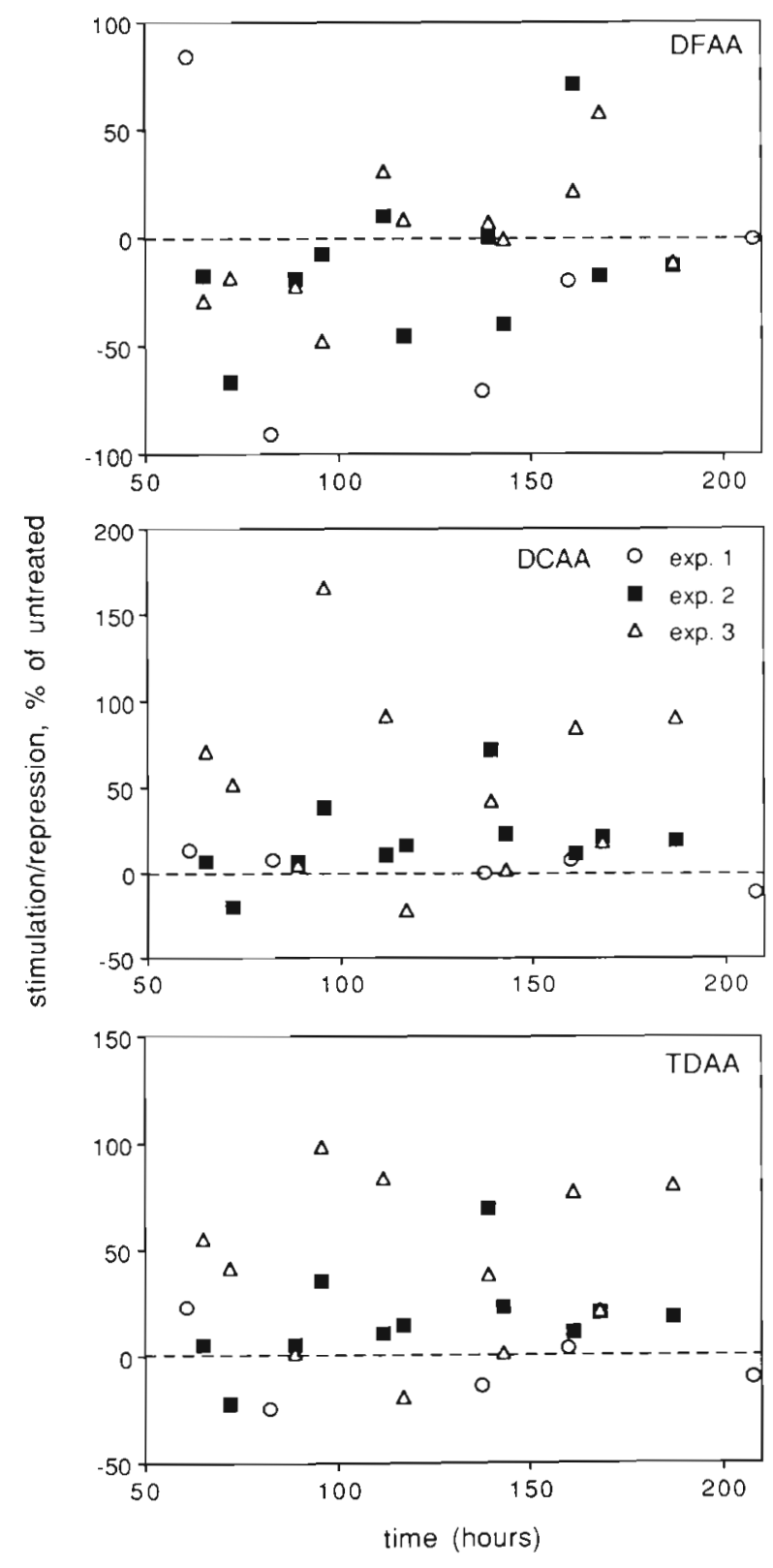

Fig. 5. Long-term stimulation/repression data of dissolved amino acids and OPA-reactive compounds during all 3 experiments. DFAA: dissolved free amino acids, DCAA: dissolved combined amino acids, TDAA: total dissolved amino acids. In Expt 3 we did not determine amino acids, but OPA-reactive compounds. Data are calculated as described in Fig. 4 
seawater was enriched with HMWC (Fig. 5). Given as a mean of the 2 experiments, stimulation was $29 \%$ for DCAA and $20 \%$ for TDAA. In Expt 3, DFORC repression averaged $13 \%$, whereas DCORC and TDORC stimulation averaged 19 and $17 \%$, respectively.

DMCHO were generally repressed in all experiments (Fig. 6) and, calculated from the means of the 3 experiments, averaged $21 \%$. Throughout all experiments, DPCHO and TDCHO concentrations were
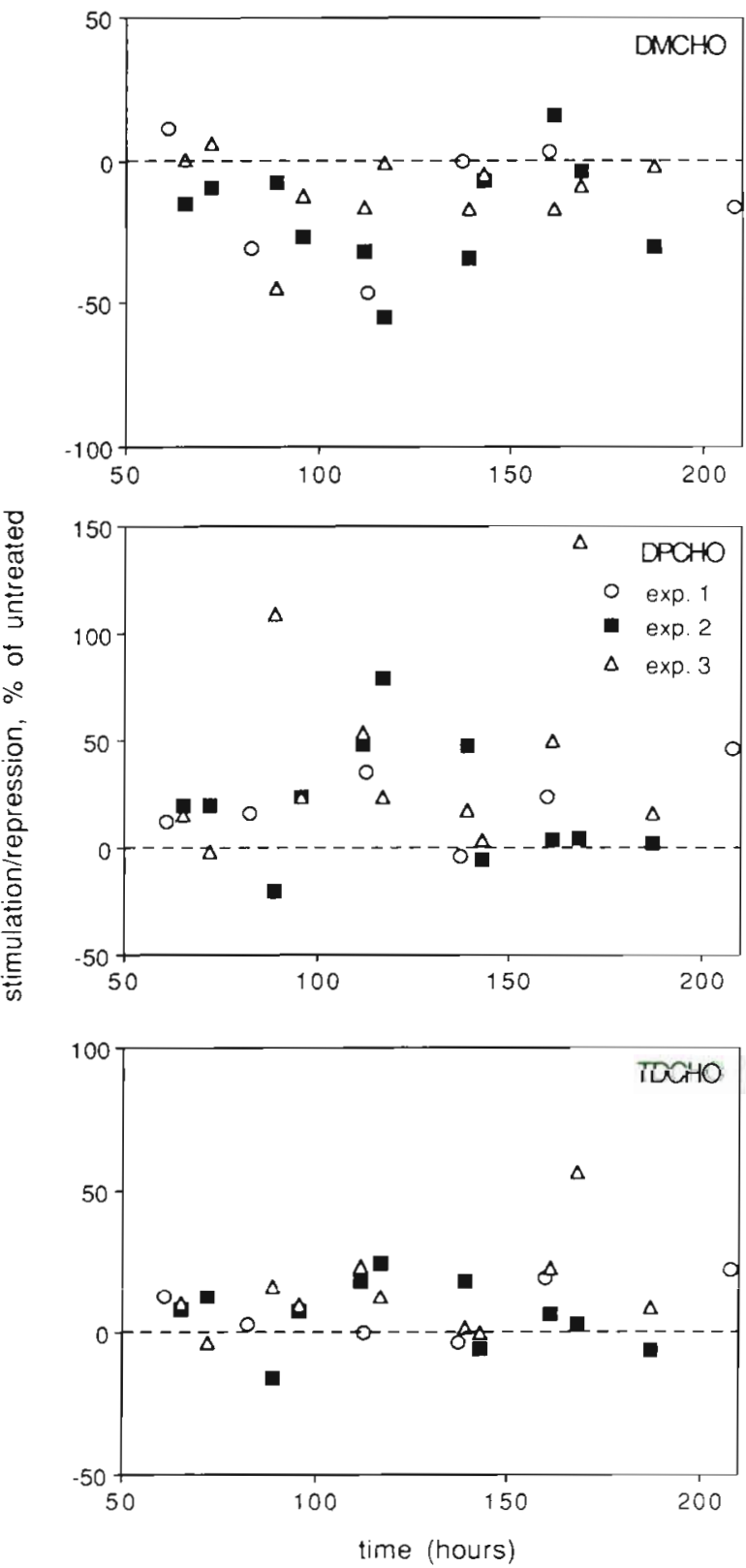

Fig. 6. Long-term stimulation/repression data of dissolved carbohydrates during all 3 experiments. DMCHO: dissolved monomenc carbohydrates, DPCHO: dissolved polymeric carbohydrates. TDCHO: total dissolved carbohydrates. Data are calculated as described in Fig. 4 higher in the HMWC enriched than in untreated incubations (Fig. 6), averaging $22 \%$ for DPCHO and $9 \%$ for TDCHO.

\section{Composition of dissolved amino acids}

In Expts 1 and 2, the percentage of single amino acids was determined in the DFAA as well as the DCAA fraction. In order to show differences between treatments we calculated the stimulation/repression of the single amino acids in the DFAA and DCAA fraction from the means of the replicate incubations (Table 3). Our data show that enrichment with HMWC resulted in a qualitative change of some of the amino acids compared to untreated incubations, when considering a stimulation/repression of $>10 \%$ as significant alteration. During the short-term experiment, Ser, His and Arg were stimulated in the HMWC enrichment in the DFAA fraction, whereas Asp, Ser, Thr and Tyr were stimulated in the DCAA fraction. During the long-term incubation in Expt 1, Asp, Ser, Tyr and Arg were stimulated in the DFAA fraction compared to Ser, Thr, Leu and Tyr in the DCAA fraction. HMWC in Expt 2 caused a stimulation in Thr, Ile and Arg in the DFAA fraction and a stimulation in Ser, Thr, Gly, Ala and Tyr in the DCAA fraction. When the 2 long-term experiments are compared with respect to stimulation/repression patterns, only Arg was stimulated in the DFAA fractions, whereas in the DCAA fractions Ser, Thr and Tyr were stimulated, and Glu and Arg were repressed.

\section{DISCUSSION}

Although the initial conditions (microbial parameters, concentrations of DOM. light and temperature conditions; compare Table 1) were different among the 3 experiments, the differences in the development of microbial and DOM parameters between HMWC-treated and unaltered incubations showed the same trends in all experiments. This implies that the bioactive nature of the HMWC had a similar effect on the development of microrganisms and DOM concentrations

In the present study we were able to show that an initial enrichment with viruses (Table 1) persisted throughout the whole experiment, with a mean viral enrichment of 2.2 (Table 2). Moreover, on the long term, the percentage of visibly infected bacteria was significantly higher in HMWC-treated than in unaltered incubations (Fig. 3). Thus, we suppose that viruses could have influenced microbial and DOM parameters throughout the experiments. Viral densi. ties observed initially in this study (Table 1) were well within the range found in the northern Adriatic Sea 
Table 3. Stimulation/repression of single dissolved amino acids in HMWC-enriched seawater. ST: short term (5.5 to 40 h); LT: long term (>60 to $208 \mathrm{~h}$ ). nd: not detectable. Values were calculated from the percentage of total amino acid concentration in each fraction (DFAA or DCAA) and averaged from all data points of an experiment

\begin{tabular}{|c|c|c|c|c|c|c|c|c|c|c|c|c|c|c|c|}
\hline \multirow{2}{*}{ Expt } & \multirow[t]{2}{*}{ Fraction } & \multicolumn{14}{|c|}{ Stimulation/repression of amino acids (\%) } \\
\hline & & Asp & Glu & Ser & Thr & Gly & Ala & Val & Ile & Leu & Tyr & Phe & His & Arg & Met \\
\hline \multirow[t]{2}{*}{ 1. $(\mathrm{ST})$} & DFAA & -3.7 & 6.6 & 12.8 & -11.0 & -14.1 & -25.1 & nd & -3.5 & nd & 4.9 & nd & 12.7 & 92.3 & nd \\
\hline & DCAA & 20.6 & -11.1 & 14.0 & 22.9 & -6.5 & 3.4 & nd & -28.6 & -26.9 & 11.8 & -26.1 & 8.3 & -10.4 & nd \\
\hline \multirow[t]{2}{*}{$1(\mathrm{LT})$} & DFAA & -6.8 & 29.1 & -9.3 & -32.1 & -2.2 & -16.0 & nd & 3.0 & nd & 40.9 & nd & -23.9 & 17.9 & nd \\
\hline & DCAA & 0.5 & -54.2 & 34.6 & 10.1 & 0.3 & 0.3 & nd & 8.9 & 28.0 & 24.8 & -3.5 & 6.0 & -12.9 & nd \\
\hline \multirow[t]{2}{*}{2} & DFAA & 7.8 & -25.0 & 7.9 & 10.8 & -5.3 & -6.9 & -3.6 & 20.8 & 5.2 & 2.0 & -10.4 & 6.7 & 26.0 & -5.8 \\
\hline & DCAA & -2.1 & -23.8 & 28.6 & 14.7 & 13.7 & 12.4 & -20.9 & -3.6 & -17.3 & 39.9 & -38.9 & -7.6 & -27.3 & -30.6 \\
\hline
\end{tabular}

$\left(0.10\right.$ to $95.5 \times 10^{6} \mathrm{ml}^{-1}$; Weinbauer et al. 1995). The moderate enrichment used in the present study avoids severely altering the system with artificially high levels of bioactive material. Suttle (1992) showed that there were at least 2 bioactive components in the HMWC which reduced primary productivity: one component is heat labile, the other is resistent to autoclaving. However, at low concentration factors of HMWC, the significance of the heat resistent component is strongly reduced compared to the heat labile component (Suttle 1992). Since the enrichment factors of the HMWC in the present study $(-2.5)$ were at the lower range of factors used in other studies (Suttle et al. 1990, Proctor \& Fuhrman 1992, Suttle 1992), we might conclude that heat labile, bioactive material caused the changes in the present study. Viruses, the most abundant particles visible by TEM in the present study, are a very probable candidate for this bioactivity (compare Suttle 1992, Proctor \& Fuhrman 1992). This is strongly supported by the finding that HMWC enrichment resulted in a significant increase of visibly infected bacteria (Fig. 3). However, there is still the possiblity that other bioactive compounds, e.g. proteins or colloids, contributed to our results.

During the short-term experiment bacterial abundance was higher in the HMWC treated than in unaltered incubations (Fig. 1). A similar phenomenon was observed by Peduzzi \& Weinbauer (1993b). Since the HMWC-enrichment procedure did not cause any dramatic stimulation of DOM concentrations (Table 1), the increase in bacterial densities does not seem to be the result of an enrichment with readily utilizable organic nutrients. Lammers (1992) showed that infection with virulent phages can increase the division rate of host bacteria. He proposed that the stimulation of bacterial cell division could be due to (1) release of nutrients by viral lysis of cells, (2) release of chemical (pheromonelike) signals influencing uninfected cells and (3) transfer of a plasmid to the bacterial community or activation of a plasmid within bacterial cells responsible for division activity. After $5.5 \mathrm{~h}$ dissolved amino acids and carbohydrates were higher in enriched than in untreated incubations, followed by a stimulation of the bacterial densities (Fig. 1). The higher DOM concentrations might have been the results of viral lysis of cells and could have caused the stimulation of bacterial growth, thus giving support to the first hypothesis of Lammers (1992).

It is also possible that the addition of HMWC induced the lytic cycle in lysogenic cells followed by a viral-mediated release of DOM. Since bacteriocins (e.g. empty virus heads and tail assemblies) are known to be capable of lysing cells (Bradley 1967, Duckworth 1970), they could also have contributed to the stimulation of DOM. Bacteriocin-like particles (viruses with empty heads and virus tail assemblies) are known to occur in seawater (Proctor \& Fuhrman 1992, Jiang \& Paul 1994); however, their actual role remains unknown. Since chl a concentrations were repressed after $18 \mathrm{~h}$ (the first time point of chl a sampling after starting the experiment; Fig. 2), lysis of phytoplankton, whether by viruses or other lytic agents, could have contributed to the increased DOM signals. This is supported by our finding that Ser and Thr were stimulated in the DCAA fraction in HMWC-treated samples during the short-term experiment (Table 3) since Ser and Thr are concentrated in the cell walls of diatoms (Hecky et al. 1973). A repression of phytoplankton within a few hours after the addition of HMWC was also observed by Suttle et al. (1990) and Suttle (1992).

In all long-term experiments HMWC enrichment resulted in a stimulation of total and hydrolysable dissolved compounds, whereas concentrations of dissolved free compounds were repressed (Figs. $5 \&$ 6). There are several reasons which could explain this observation. Three of them, which might act simultaneously, are discussed here.

First, if the repression of bacteria and phytoplankton during the long-term study (Figs. $2 \& 4$ ) is actually due to lysis by viruses or bacteriocins, then the release of cell wall constituents and cell content could have contributed to the observed changes in DOM. Since bacte- 
rial and phytoplankton cells are mainly composed of hydrolysable compounds, lysis of cells might not only explain the higher concentrations of total dissolved amino acids, OPA-reactive compounds and carbohydrates but also the stimulation of hydrolysable DOM compounds (Figs. $5 \& 6$ ). The higher frequency of visibly infected bacteria in HMWC-treated incubations supports the above outlined argument (Fig. 3). Since Ser and Thr are concentrated in the cell walls of diatoms (Hecky et al. 1973), the stimulation of Ser and Thr in the DCAA fraction in enriched incubations (Table 3) might have resulted from lysis of diatom cells, the dominant phytoplankton organisms in the present study. Ser, Gly and Ala are the most abundant amino acids of whole phytoplankton cells (Daumas 1976). Interestingly, none of these amino acids in the DCAA fraction was repressed in long-term experiments (Table 3), supporting the idea of amino acid release due to viral lysis of phytoplankton. Bioactive compounds other than viruses may be present in the HMWC, affecting the concentrations of bacteria (Proctor \& Fuhrman 1992) and phytoplankton (Suttle 1992) and contributing to the observed differences of DOM between unaltered and enriched incubations.

Secondly, although viruses can infect flagellates (Nagasaki et al. 1993), it was demonstrated in previous experiments that the addition of HMWC increased rather than repressed heterotrophic flagellate abundances, probably as a result of grazing on initially increased bacteria as well as on viruses (Peduzzi \& Weinbauer 1993b, Pesan et al, 1994). Thus, release of DOM by flagellates due to grazing activity or excretion (Andersson et al. 1985, Nagata \& Kirchman 1991, 1992) may have contributed to the stimulation/repression pattern of amino acids, OPA-reactive compounds and Carbohydrates. Based on the observed stimulation of DCAA, DCORC and DPCHO in enriched incubations, a possible DOM release by flagellate grazing should have contributed mainly hydrolysable compounds. This is supported by findings suggesting that flagellates might produce colloids (Koike et al. 1990, Tranvik 1994). Although grazing by zooplankton is also known to produce DOM, either by 'sloppy feeding' or excretion (e.g. Jumars et al. 1989, Peduzzi \& Herndl 1992), this mechanism can hardly explain the stimulation/ repression pattern of DOM, since zooplankton (copepods) were present (but scarcely) in only one of our experiments (unpubl. data).

As a third process, the lower bacterial densities caused by the addition of HMWC might have resulted in differences of DOM uptake between enriched and untreated incubations. Lower bacterial (Fig. 4) density or repressed activity might have caused accumulation of DOM. During long term incubations DFAA, DFORC and DMCHO concentrations were repressed simulta- neously with repression in bacterial numbers. One explanation for this finding might be that overall enzymatic hydrolysis of macromolecular compounds was reduced due to low bacterial numbers. This could well result in lower concentrations of readily utilizable DOM (DFAA, DFORC and DMCHO) as well as in higher concentrations of total and hydrolysable compounds. However, we do not have data on bacterial production or enzyme activity. Bacterial morphotypes differ, e.g. with respect to the percentage of cells containing mature phages (Weinbauer \& Peduzzi 1994). In the present study, HMWC significantly increased the percentage of infected rod-shaped bacteria. In the case of phytoplankton, it was demonstrated that HMWC predominantly affected only a part of the phytoplankton community, i.e. cells $>3 \mu \mathrm{m}$ (Suttle 1992). Thus, the addition of viruses might have influenced the composition of the bacterial community and consequently the degradation and transformation of DOM.

In previous studies it was shown that HMWC can cause changes in the dynamics of phytoplankton, bacteria and flagellates (Proctor \& Fuhrman 1992, Suttle 1992, Peduzzi \& Weinbauer 1993b). In the present study we demonstrated that the HMWC also change the concentration and chemical composition of selected components of the DOM pool. However, it can be anticipated that viral lysis has a more profound effect on the recycling rates than on standing stocks of biomass or DOM (Fuhrman 1992). Thus, the presence of viruses and other bioactive substances in this size fraction could have important consequences for the cycling of organic carbon in the oceans.

Acknowledgements. The authors are grateful to the Institute of Zoology for laboratory space, W. Klepal for providing TEM equipment, G. J. Herndl for discussions and support and J. A Ott for valuable comments. We also appreciate all members of the working group of G. J. Herndl for assistence during field and lab work. A. Helssenberger performed HPLC analyses and was the driving force for the application of the hydrolysis assay for the dissolved carbohydrates used in this study. $C$. Suttle and 3 anonymous reviewers gave valuable comments on the manuscript. Special thanks are due F. Starmühlner for making the study possible. This work was supported by the Austrian Sclence Foundation, grant P 8335 to P.P.

\section{LITERATURE CITED}

Andersson A, Lee C, Azam F. Hagström A (1985) Release of amino acids and inorganic nutrients by heterotrophic marine microflagellates. Mar Ecol Prog Ser 23:99-106

Bergh Ø, Børsheim KY, Bratbak G, Heldal M (1989) High abundance of viruses found in aquatic environments. Nature 340:467-468

Boehme J, Frischer ME, Jiang SC, Kellogg CA, Pichard S, Rose JB, Steinway C, Paul JH (1993) Viruses, bacterioplankton, and phytoplankton in the southeastern Gulf of Mexico: distribution and contribution to oceanic DNA pools. Mar Ecol Prog Ser 97:1-10 
Borsheim KY, Bratbak G, Heldal M (1990) Enumeration and biomass estimation of planktonic bacteria and viruses by transmission electron microscopy. Appl environ Microbiol $56: 352-356$

Bradley DE (1967) Ultrastructure of bacteriophages and bacteriocins. Bact Rev 31:230-314

Bratbak G, Heldal M, Norland S, Thingstad TF (1990) Viruses as partners in spring bloom microbial trophodynamics. Appl environ Microbiol 56:1400-1405

Bratbak G, Heldal M, Thingstad TF, Riemann B, Haslund OH (1992) Incorporation of viruses into the budget of microbial C-transfer. A first approach. Mar Ecol Prog Ser 83: 273-280

Bratbak G, Thingstad F, Heldal $M$ (1994) Viruses and the microbial loop. Microb Ecol 28:209-221

Cochlan WP, Wikner J, Steward GF, Smith DC, Azam F (1993) Spatial distribution of viruses, bacteria and chlorophyll a in neritic, oceanic and estuarine environments. Mar Ecol Prog Ser 92:77-87

Daumas R (1976) Variations in particulate proteins and dissolved amino acids in coastal seawater. Mar Chem 4: 225-242

Duckworth DH (1970) Biological activity of bacteriophage ghosts and 'take-over' of host functions by bacteriophage. Bact Rev 34:344-363

Fuhrman J (1992) Bacterioplankton roles in cycling of organic matter: the microbial food web. In: Falkowski PG, Woodhead AD (eds) Primary productivity and biogeochemical cycles in the sea. Plenum Press, New York, p 361-383

Gowing MM (1993) Large virus-like particles from vacuoles of phaeodarian radiolarians and from other marine samples. Mar Ecol Prog Ser 101:33-43

Hecky RE, Mopper K, Kilham P, Degens ET (1973) The amino acid and sugar composition of diatom cell walls. Mar Biol $19: 838-863$

Heissenberger A, Herndl GJ (1994) Formation of high molecular weight material by free-living marine bacteria. Mar Ecol Prog Ser 111:129-135

Hobbie JE, Daley RJ, Jasper S (1977) Use of Nuclepore filters for counting bacteria by epifluorescence microscopy. Appl environ Microbiol 33:1225-1228

Jiang SC, Paul JH (1994) Seasonal and diel abundance of viruses and occurrence of lysogeny/bacteriocinogeny in the marine environment. Mar Ecol Prog Ser 104: $163-172$

Jumars PA, Penry DL, Baross JA, Perry MJ, Frost BW (1989) Closing the microbial loop: dissolved carbon pathway to heterotrophic bacteria from incomplete ingestion, digestion and absorption in animals. Deep Sea Res 36:483-495

Koike 1, Hara S, Terauchi K, Kogure K (1990) Role of submicrometre particles in the ocean. Nature 345:242-244

Lammers WT (1992) Stimulation of bacterial cytokinesis by bacteriophage predation. Hydrobiologia 235/236:261-265

Mathews J, Buthala DA (1970) Centrifugal sedimentation of virus particles for electron microscopy counting. J Virol 5 : 598-603

Mopper K, Lindroth P (1982) Diel and depth variations in dissolved free amino acids and ammonium in the Baltic Sea determined by shipboard HPLC analysis. Limnol Oceanogr 27:336-347

Murray AG, Eldridge PM (1994) Marine viral ecology: incorporation of bacteriophage into the microbial planktonic food web paradigm. J Plankton Res 627-641

Nagasaki K, Ando M. Imai l, Itakura S, Ishida Y (1993) Viruslike particles in an apochlorotic flagellate in Hiroshima Bay, Japan. Mar Ecol Prog Ser 96:307-310

Nagata T, Kirchman DL (1991) Release of dissolved free and combined amino acids by bacterivorous marine flagellates. Limnol Oceanogr 36:433-443

Nagata T, Kirchman DL (1992) Release of macromolecular organic complexes by heterotrophic marine flagellates. Mar Ecol Prog Ser 83:233-240

Parsons T, Maita Y, Lalli C (1984) A manual of chemical and biological methods for seawater analysis. Pergamon Press, Oxford

Paul JH, Rose JB, Jiang SC, Kellogg CA, Dickson L (1993) Distribution of viral abundance in the reef environment of Key Largo, Florida. Appl environ Microbiol 59:718-724

Peduzzi P. Herndl GJ (1992) Zooplankton activity fueling the microbial loop: differential growth response of bacteria from oligotrophic and eutrophic waters. Limnol Oceanogr $37: 1087-1092$

Peduzzi P. Weinbauer MG (1993a) Effect of concentrating the virus-rich 2-200 $\mathrm{nm}$ size fraction of seawater on the formation of algal flocs (marine snow). Limnol Oceanogr 38: $1562-1565$

Peduzzi P, Weinbauer MG (1993b) The submicron size fraction of seawater containing high numbers of virus particles as bioactive agent in unicellular plankton community successions. J Plankton Res 15:1375-1386

Pesan BF, Weinbauer MG, Peduzzi P (1994) Significance of the virus-rich $2-200 \mathrm{~nm}$ size fraction of seawater for heterotrophic flagellates. I. Impact on growth. PSNZ I: Mar Ecol 15: 281-290

Proctor LM, Fuhrman JA (1990) Viral mortality of marine bacteria and cyanobacteria. Nature 343:60-62

Proctor LM, Fuhrman JA (1992) Mortality of marine bacteria in response to enrichments of the virus size fraction from seawater. Mar Ecol Prog Ser 87:283-293

Sieburth JM, Johnson PW, Hargraves PE (1988) Ultrastructure and ecology of Aureococcus anophagefferens gen et sp. nov. (Chrysophyceae): the dominant picoplankter during a bloom in Narragansett Bay, Rhode Island, summer 1985. J Phycol 24:416-425

Steward GF, Wikner J, Cochlan WP, Smith DC, Azam F (1992) Estimation of virus production in the sea: II. Field results. Mar Microb Food Webs 6:79-90

Suttle CA (1992) Inhibition of photosynthesis in phytoplankton by the submicron size fraction concentrated from seawater. Mar Ecol Prog Ser 87:105-112

Suttle CA (1994) The significance of viruses to mortality in aquatic microbial communities. Microb Ecol 28:237-243

Suttle CA, Chan AM, Cottrell MT (1990) Infection of phytoplankton by viruses and reduction of primary productivity Nature 347:467-469

Suttle CA, Chan AM, Cottrell MT (1991) Use of ultrafiltration to isolate viruses from seawater which are pathogens of marine phytoplankton. Appl environ Microbiol 57:721-726

Tranvik L (1994) Colloidal and dissolved organic matter excreted by a mixotrophic flagellate during bacterivory and autotrophy. Appl environ Microbiol 60:1884-1888

Weinbauer MG, Fuks D, Peduzzi P (1993) Distribution of viruses and dissolved DNA along a coastal trophic gradient in the northern Adriatic Sea. Appl environ Microbiol 59:4074-4082

Weinbauer MG, Fuks D, Puskaric S, Peduzzi P (1995) Diel, seasonal and depth-related variability of viruses and dissolved DNA in the northern Adriatic Sea. Microb Ecol 30:25-41

Weinbauer MG, Peduzzi P (1994) Frequency, size and distribution of bacteriophages in different marine bacterial morphotypes. Mar Ecol Prog Ser 108:11-20

Wommack KE, Hill RT, Kessel M, Russek-Cohen E, Colwell RR (1992) Distribution of viruses in the Chesapeake Bay. Appl environ Microbiol 58:2965-2970

Manuscript first received: December 1, 1994

Revised version accepted: May 4, 1995 